\title{
Standardization and validation of a cytometric bead assay to assess antibodies to multiple Plasmodium falciparum recombinant antigens
}

Bartholomew N Ondigo ${ }^{1,3^{*}}$, Gregory S Park², Severin O Gose ${ }^{2}$, Benjamin M Ho², Lyticia A Ochola', George O Ayodo ${ }^{3}$, Ayub V Ofulla ${ }^{1}$ and Chandy C John ${ }^{2}$

\begin{abstract}
Background: Multiplex cytometric bead assay (CBA) have a number of advantages over ELISA for antibody testing, but little information is available on standardization and validation of antibody CBA to multiple Plasmodium falciparum antigens. The present study was set to determine optimal parameters for multiplex testing of antibodies to $P$. falciparum antigens, and to compare results of multiplex CBA to ELISA.

Methods: Antibodies to ten recombinant P. falciparum antigens were measured by CBA and ELISA in samples from 30 individuals from a malaria endemic area of Kenya and compared to known positive and negative control plasma samples. Optimal antigen amounts, monoplex vs multiplex testing, plasma dilution, optimal buffer, number of beads required were assessed for CBA testing, and results from CBA vs. ELISA testing were compared.

Results: Optimal amounts for CBA antibody testing differed according to antigen. Results for monoplex CBA testing correlated strongly with multiplex testing for all antigens ( $r=0.88-0.99$, $P$ values from $<0.0001-0.004)$, and antibodies to variants of the same antigen were accurately distinguished within a multiplex reaction. Plasma dilutions of 1:100 or 1:200 were optimal for all antigens for CBA testing. Plasma diluted in a buffer containing $0.05 \%$ sodium azide, $0.5 \%$ polyvinylalcohol, and $0.8 \%$ polyvinylpyrrolidone had the lowest background activity. CBA median fluorescence intensity (MFI) values with 1,000 antigen-conjugated beads/well did not differ significantly from MFI with 5,000 beads/well. CBA and ELISA results correlated well for all antigens except apical membrane antigen-1 (AMA-1). CBA testing produced a greater range of values in samples from malaria endemic areas and less background reactivity for blank samples than ELISA.

Conclusion: With optimization, CBA may be the preferred method of testing for antibodies to $P$. falciparum antigens, as CBA can test for antibodies to multiple recombinant antigens from a single plasma sample and produces a greater range of values in positive samples and lower background readings for blank samples than ELISA.
\end{abstract}

Keywords: Multiplex, Malaria, Antibodies, ELISA

\section{Background}

Most studies that have determined antibody responses to Plasmodium falciparum antigens and vaccine candidates in human plasma samples have used enzyme linked immunosorbent assay (ELISA) [1,2]. Recent advances in bead-based flow cytometry have made multiplex cytometric bead assay

\footnotetext{
* Correspondence: ondigo2002@yahoo.com

'Department of Biomedical Science and Technology, Maseno University, Maseno, Kenya

${ }^{3}$ Center for Global Health Research, Kenya Medical Research Institute, Kisumu, Kenya

Full list of author information is available at the end of the article
}

(CBA) antibody testing an attractive alternative to ELISA testing. The Luminex ${ }^{100}$ system can simultaneously quantitate up to 100 different proteins, peptides, DNA fragments or RNA fragments from a $5 \mu \mathrm{l}$ sample in one well of a microtiter plate [3]. The multiplex assay is a bead format assay in which each bead set is internally color-coded with different ratio of red to infrared dyes, such that the Luminex ${ }^{100}$ can classify each bed set separately. The beads in multiplex assay anchor the antigens, as opposed to ELISA where the surfaces of the wells of microtiter plate anchor the antigen. The Luminex ${ }^{100}$ has two lasers; one laser beam 
excites the internal colored dyes for classification of the bead sets, while the other laser excites the reporter fluorochrome phycoerythrin (PE) [4,5]. Through classification of the bead set, various bead sets are distinguished, which correspond to up to 100 different analytes that the machine can quantitate, while the amount of analyte present in the plasma, serum or supernatant is quantified by excitation of the reporter fluorochrome [6].

Prior studies have reported use of the multiplex assay for antibody determination to P. falciparum antigens [7-11], and comparison studies of multiplex antibody measurements and traditional monoplex ELISA have shown a high correlation $[4,11,12]$. However, these studies have used a variety of different protocols and test antigens. There are, to date, limited published studies that provide information on assay optimization conditions or comparisons of antigen and plasma concentrations for multiplex testing. To provide standards for testing that will allow wider use of this technique by other researchers, optimal parameters for multiplex assay were determined and compared with results of ELISA. The assessed assay characteristics included: the optimal malaria antigen amount for CBA, optimal plasma dilutions for both CBA and ELISA assays, plasma buffer choice for CBA, comparison of MFI between single vs. multiplex CBA, optimization of the numbers of microspheres per reaction for CBA, testing of CBA readout with multiple variants of an antigen in a single test, and comparison of optimized CBA with ELISA.

\section{Methods}

\section{Plasma samples}

For validation and standardization of the multiplex assay of antibodies to P. falciparum antigens, a plasma pool made of 30 plasma samples from adults living in a Ugandan area of seasonal malaria transmission (positive control pool samples) [13] and seven plasma samples from North American individuals never exposed to malaria (negative control samples) was used. For comparison of antibody testing by CBA and ELISA to multiple P. falciparum antigens, samples from 30 individuals from a malaria endemic area of western Kenya were used [14]. Kenyan samples were obtained from both children and adults, to enable testing of a broad range of antibody values. Written informed consent was obtained from the study participants or, in the case of minors, from their parent or guardian. Ethical approval for the study was obtained from Kenya Medical Research Institute National Ethical Review Committee and the Institutional Review Boards of Makerere University and University of Minnesota.

\section{Plasmodium falciparum recombinant and peptide antigens} The ten recombinant $P$. falciparum antigens used for testing were apical membrane antigen-1 (AMA-1, full length ectodomain, 3D7 and FVO strains), erythrocytebinding antigen (EBA-175, non-glycosylated region II), glutamate rich protein (GLURP, conserved non-repeat $\mathrm{N}$-terminal region, amino acids $25-514, \mathrm{R} 0$; and repeat C-terminal region, amino acids 705-1178, R2, 3D7 strain), merozoite surface protein-1 (MSP-1 19 , E-KNG variant; $\mathrm{MSP}-1_{42}, 3 \mathrm{D} 7, \mathrm{FUP}$ and FVO strains), and merozoite surface protein-3 (MSP-3, C-terminus, FVO strain) were used for testing. Recombinant AMA-1 was expressed in Escherichia coli and provided by David Lanar, Walter Reed Army Institute for Research. Recombinant MSP-1 $1_{42}$ and MSP-3 were expressed in Escherichia coli, and recombinant EBA-175 was expressed in Pichia pastoris, and provided by David Narum, National Institutes of Health. Recombinant GLURP was expressed in Escherichia coli and provided by Michael Theisen, Statens Seruminstitut, Copenhagen, Denmark. Recombinant MSP- $1_{19}$ expressed in Saccharomyces cerivisiae, was provided by the Malaria Research and Reference Reagent Resource Center (Manassas, VA), and originally deposited there by David Kaslow. Blank samples consisted of the plasma diluent alone.

\section{Coupling of recombinant antigens to microspheres for the cytometric bead assay (CBA)}

Microspheres were purchased from Luminex Corporation (Austin, TX). The bead stock was resuspended by gentle inversion for $1 \mathrm{~min}$. An aliquot of 612, 500 beads was removed and centrifuged at 16, $000 \mathrm{~g}$ (Labnet Wood bridge, NJ) for $3 \mathrm{~min}$. After discarding the supernatant, $100 \mu \mathrm{l}$ of distilled water was added and centrifuged at $16,000 \mathrm{~g}$ for $3 \mathrm{~min}$. Beads were resuspended in $80 \mu \mathrm{l}$ of activation buffer, $100 \mathrm{mM}$ monobasic sodium phosphate (Sigma, S3139); pH 6.2, by vortexing (Scientific Industries Bohemia, NY) and sonication, $20 \mathrm{sec}$ each. To activate the beads for cross-linking to proteins, $10 \mu \mathrm{l}$ of $50 \mathrm{mg} / \mathrm{mlN}$ - hydroxysulfosuccinimide sodium salt (Sigma, 56485) was added to the beads and mixed by vortexing for $10 \mathrm{sec}$ at moderate speed. Next, $10 \mu \mathrm{l}$ of $50 \mathrm{mg} / \mathrm{ml} \mathrm{N}$-[3dimethylaminopropyl] - N'-ethylcarbodiimidehydrochloride (Sigma, E1769) was added and the beads mixed again by vortexing for $10 \mathrm{sec}$ at moderate speed. All incubations of beads were performed in the dark (covered with foil). The bead mixture was rotated on a rotary shaker (Labnet Edison, NJ) at room temperature for $20 \mathrm{~min}$ and vortexed for $10 \mathrm{sec}$ at $10 \mathrm{~min}$ and at $20 \mathrm{~min}$, both at moderate vortexing speed. Beads were pelleted by centrifuging at $16,000 \mathrm{~g}$ for $5 \mathrm{~min}$ and washed twice with $250 \mu \mathrm{l}$ of $100 \mathrm{mM}$ morpholineethane sulfonic acid (MES), (Sigma, M2933), pH 6.0 buffer. Finally, beads were centrifuged at 16 , $000 \mathrm{~g}$ for $5 \mathrm{~min}$ to pellet. To coat the beads with antigens, pelleted beads were resuspended with the relevant antigen and the volume adjusted to $500 \mu \mathrm{l}$ per reaction by addition of coupling buffer (100 mM MES pH 
6.0). Beads were conjugated to $0.5,1,2$ and 5,10 and 1,000 $\mu \mathrm{g}$ of different antigens. The antigen and activated beads mixture was incubated on a rotary shaker for $2 \mathrm{~h}$ at room temperature in the dark to allow bead coupling to occur. After being coated with proteins beads were centrifuged at $16,000 \mathrm{~g}$ for $3 \mathrm{~min}$ and washed twice with $250 \mu \mathrm{l}$ of PBSTBN (PBS, 0.1\% BSA, 0.02\% Tween, 0.05\% sodium azide) and resuspended in $200 \mu \mathrm{l}$ of PBS-TBN. To determine the percentage recovery after the coupling procedure, coupled beads were counted on a haemocytometer (Hausser Scientific Horsham, PA).

\section{Testing for IgG antibodies to $P$. falciparum antigens by CBA}

The volume of working solution $(50 \mu \mathrm{l} /$ well $)$ was calculated together with the number of beads that would result in 1,000 beads/region/well or 5,000 beads/region/well. Bead stocks were then combined in a $15 \mathrm{ml}$ amber conical tube and diluted with PBNT (0.1\% BSA, 0.05\% Tween 20, $0.05 \%$ sodium azide in PBS) to result in 100 microspheres/ $\mu \mathrm{l}$ or 20 microspheres $/ \mu \mathrm{l}$. 96 well-millipore microtiter plates (MABVN 1250, Millipore corporation, Billerica, MA) were pre-wetted with $100 \mu \mathrm{l}$ of PBNT/well and aspirated using a millipore vacuum manifold and 50 $\mu \mathrm{l}$ of working bead solution was transferred to it. Plasma samples were thawed at room temperature, mixed and centrifuged at $16,000 \mathrm{~g}$ for $3 \mathrm{~min}$. Plasma was diluted through a series of concentrations: 1:100, 1:200, 1:400, 1:1000, 1:2000 and 1:4000. Plasma samples were diluted in either buffer A (1xPBS, $0.1 \%$ BSA, $0.05 \%$ Tween 20 , and $0.05 \%$ sodium azide) or buffer B (1xPBS, 1\% BSA, $0.05 \%$ Tween $20,0.05 \%$ sodium azide, $0.5 \%$ polyvinylalcohol, and $0.8 \%$ polyvinylpyrrolidone). Buffer $\mathrm{A}$ is the standard buffer used by other studies of multiplex CBA for P. falciparum antigens [9], while buffer $B$ has been used for multiplex antibody testing to other antigens and found to decrease background reactivity [15].

Fifty $\mu \mathrm{l}$ of diluted plasma was added to each of the well of the microtiter plate. The plasma was mixed with the beads three times by pipetting up and down. The plates were incubated in the dark on a shaking microplate shaker (IKA ${ }^{\circledR}$ MTS, Wilmington, NC) at $600 \mathrm{rpm}$ for $30 \mathrm{sec}$, followed by $300 \mathrm{rpm}$ for $30 \mathrm{~min}$. Plates were aspirated using a millipore vacuum manifold and washed twice with $100 \mu \mathrm{l} /$ well of PBNT, and beads were resuspended in $50 \mu \mathrm{l}$ PBNT by pipetting. $50 \mu \mathrm{l}$ of diluted 1:1,000 goat antihuman IgG (gamma- chain specific, $F$ (ab')2 fragment-R-phycoerythrin (Sigma, P-8047 St. Louis, $\mathrm{MO}$ ) in PBNT was added to each well, and incubated in the dark with shaking at $600 \mathrm{rpm}$ for $30 \mathrm{sec}$, followed by $300 \mathrm{rpm}$ for $30 \mathrm{~min}$. Plates were aspirated using a millipore vacuum manifold and washed twice with $100 \mu \mathrm{l} /$ well PBNT. The beads were resuspended in $100 \mu \mathrm{l}$ PBNT by mixing and analysed on bioplex machine (Hercules, CA).
The reader was set to read a minimum of 100 beads with of unique fluorescent signature/region and the results expressed as median fluorescence intensity (MFI).

\section{Testing for IgG antibodies to $P$. falciparum antigens by ELISA}

To validate the multiplex assay, similar plasma samples were tested for IgG antibodies to the same P. falciparum antigens by enzyme-linked immunosorbent assay (ELISA). Recombinant antigens were dissolved in 0.01 M PBS to concentrations: $0.1 \mu \mathrm{g} / \mathrm{ml}$ for (AMA-1 3D7, AMA-1 FVO, EBA-175 and GLURP-R2), $0.2 \mu \mathrm{g} / \mathrm{ml}$ for (MSP- $1_{42}$ FVO, MSP- $1_{42} 3$ D7, and MSP- $1_{42}$ FUP), $0.5 \mu \mathrm{g} / \mathrm{ml}$ for (GLURPR0, MSP- $1_{19}$ and MSP-3 FVO). These antigen concentrations were found to be optimal in previous studies for AMA-1, EBA-175, MSP-1 42 [1], GLURP-R0 [16-19], GLURP-R2 [16,18], MSP-1 19 [20] and MSP-3 [21]. Fifty microlitres of antigen solution was added to Immulon-4 plates (Dynex Technologies,Chantilly, VA). Following overnight incubation at $4^{\circ} \mathrm{C}$, washing with PBS- $0.05 \%$ Tween 20 , and blocking in $5 \%(\mathrm{wt} / \mathrm{vol})$ nonfat powdered milk in PBS, duplicate $50 \mu \mathrm{l}$ samples of serum diluted through a series of concentrations ranging from 1:50, 1:100, 1:200, 1:500, 1:1000, and 1:2000 in 5\% powdered milk were added to wells and incubated for $2 \mathrm{~h}$ at room temperature. After washing with PBS $-0.05 \%$ Tween $20,50 \mu \mathrm{l}$ of alkaline phosphatase-conjugated goat anti-human IgG (Jackson ImmunoResearch, West Grove, PA) diluted 1:1,000 in 5\% powdered milk was added and incubated for $1 \mathrm{~h}$. After extensive washing with PBS-0.05\% Tween 20, $p$-nitrophenylphosphate was added in accordance with the manufacturer's instructions (Sigma, S0942 St. Louis, MO). The optical density (OD) was measured at $405 \mathrm{~nm}$ (Molecular Devices, Sunnyvale, CA).

\section{Statistical analysis}

The degree of association between MFI or OD values was assessed using Pearson's correlation ( $r$ ). Comparison of MFI values with Buffer A vs. Buffer B was done using Student's t-test. All statistical tests were 2 -sided and a $P$ value of less than or equal to 0.05 was considered to be statistically significant for all comparisons. Analyses were conducted with Stata software version 10.0 (Stata Corporation, College Station, TX).

\section{Results}

Optimal amount of antigen for multiplex CBA

To determine optimal amounts of antigen for testing, 612,500 beads were coupled with differing amounts of antigens (Table 1). For antigen amount testing, the coated beads were incubated with plasma diluted to 1:200 from the positive pool sample (a mixture of plasma from 30 adults from a malaria seasonal transmission area of Uganda). Antigen amounts of $0.5,1,2,5$ and $10 \mu \mathrm{g}$ of 
Table 1 Parameters tested in the CBA assay

\begin{tabular}{|c|c|c|c|}
\hline $\begin{array}{l}\text { Experimental condition } \\
\text { tested }\end{array}$ & Values tested & Type and number of plasma samples used & Outcome \\
\hline Amount of antigen & $0.5,1,2,5$ and $10 \mu \mathrm{g}$ & $\begin{array}{l}\text { Positive pool (see Methods) in duplicate } \\
\text { wells per antigen amount }\end{array}$ & $\begin{array}{l}\text { Different antigens had different } \\
\text { optimal amounts (see Results) }\end{array}$ \\
\hline Plasma buffer component & \multirow{2}{*}{$\begin{array}{l}\text { BSA, polyvinyl alcohol, polyvinylpyrrolidone } \\
\text { concentrations }\end{array}$} & \multirow{4}{*}{$\begin{array}{l}\text { North American (non-malaria exposed) } \\
\text { control pool and positive plasma pool }\end{array}$} & \multirow{4}{*}{$\begin{array}{l}\text { Buffer B had similar MFI values to } \\
\text { Buffer A for positive plasma pool } \\
\text { samples, but lower MFI values } \\
\text { than Buffer A for NA controls }\end{array}$} \\
\hline BSA & & & \\
\hline Polyvinylalcohol & \multirow{2}{*}{$\begin{array}{l}\text { Buffer A }(0.1 \%, 0 \%, 0 \%) \text { vs. Buffer B } \\
(1 \%, 0.5 \%, 0.8 \%)\end{array}$} & & \\
\hline Polyvinylpyrrolidone & & & \\
\hline Plasma dilution & $\begin{array}{l}1: 100,1: 200,1: 400,1: 1,000,1: 2,000 \text { and } \\
1: 4,000\end{array}$ & $\begin{array}{l}30 \text { samples from persons from a malaria } \\
\text { endemic area, } 7 \text { North American control } \\
\text { samples and duplicate positive pool } \\
\text { plasma samples }\end{array}$ & Optimal 1:100 or $1: 200$ \\
\hline \multirow[t]{2}{*}{ Assay format } & Monoplex (each Ag) & \multirow[t]{2}{*}{8 malaria endemic plasma samples } & \multirow{2}{*}{$\begin{array}{l}\text { Multiplex and monoplex gave } \\
\text { similar values }\end{array}$} \\
\hline & Multiplex (10 different Ags) & & \\
\hline $\begin{array}{l}\text { Number of microspheres } \\
\text { per reaction }\end{array}$ & $\begin{array}{l}5000 \text { beads/analyte/well, } 1000 \text { beads/ } \\
\text { analyte/well }\end{array}$ & $\begin{array}{l}3 \text { North American, } 16 \text { malaria endemic } \\
\text { samples }\end{array}$ & $\begin{array}{l}1000 \text { and } 5000 \text { beads/analyte/well } \\
\text { gave similar values }\end{array}$ \\
\hline \multirow[t]{2}{*}{ Reproducibility } & 0 day & \multirow{2}{*}{$\begin{array}{l}\text { Positive pool, } 2 \text { North American and } 3 \\
\text { malaria endemic samples }\end{array}$} & \multirow[t]{2}{*}{ Highly reproducible results } \\
\hline & 7 days later & & \\
\hline
\end{tabular}

Parameters optimized in the multiplex cytometric bead based assay (CBA) assay with a set of variables investigated, description of samples used and standardized values that gave optimal results.

antigen were each used to coat duplicate wells, and a positive pool sample was placed in each well. The optimal antigen amount was the amount that yielded the highest average MFI value. The optimal amount for MSP- $1_{42}$ FUP, MSP- $1_{42}$ 3D7 and GLURP-R0 was $0.5 \mu \mathrm{g}$; for AMA-1 3D7, MSP-1 $1_{22}$ FVO,MSP-3 FVO was $1 \mu \mathrm{g}$; for AMA-1 FVO and EBA-175 was $2 \mu \mathrm{g}$; and for MSP- $1_{19}$ was $10 \mu \mathrm{g}$. The optimal amount for GLURP-R2 was not tested separately, and the same amount as for GLURP-R0 (0.5 $\mu \mathrm{g})$ was used in multiplex testing.

\section{Monoplex and multiplex CBA formats}

To determine how multiplexing influences MFI values in CBA assay, monoplex and multiplex assays were compared using the full 10-plex of $P$. falciparum antigens. Plasma IgG antibodies against each antigen were tested in a monoplex format (10 antigens tested separately) and as a 10-plex assay (in which antibodies to all antigens were tested in a single reaction well). For this experiment, eight plasma samples from individuals from malaria endemic area were used, and 5,000 beads/region/well were tested (Table 1). Plasma samples were diluted 1:200 (Figure 1). Results showed that MFI values for monoplex and multiplex were similar and statistically significant correlations between the two formats for all antigens was observed, with a Pearson's correlation coefficient $(r)$ ranging from 0.88 to 0.99 , and all $P$ values $<0.0001$ except for MSP-1 $1_{42}$ FUP, $P=0.004$ and MSP-1 $1_{42} 3 \mathrm{D} 7$, $P=0.0003$. Importantly, microspheres coupled to different allelic variants of the same antigen did not differ in monoplex $v s$ multiplex testing, demonstrating that there were no significant problems with crossreactivity in multiplex testing, even with multiple variants of the same antigen included in testing.

\section{Optimal plasma dilution for multiplex CBA and ELISA assays}

Optimal plasma dilution was determined by both multiplex CBA and ELISA for each antigen. Thirty samples from individuals from a malaria endemic area of Kenya, seven samples from North Americans never exposed to malaria and positive pool plasma samples were used for this testing (Table 1). Plasma was diluted to concentrations of 1:100, 1:200, 1:400, 1:1000, 1:2000 and 1:4000 for CBA, and 1:100, 1:200, 1:500, 1:1000 and 1:2000 for ELISA. Different concentration ranges were chosen because OD values of ELISA decreased more rapidly than MFI values, such that values at 1:2000 were extremely low and approached North American control values for instance MSP-3 and MSP-1 19 (Figure 2). In contrast, the MFI values of CBA at 1:2000 were still well above North American control values. Multiplex CBA testing demonstrated consistently low MFI values for samples from North Americans never exposed to malaria, and these values generally decreased as plasma dilution increased (Figure 3). Plasma dilution of 1:100 provided the highest OD on ELISA testing for all antigens while mean MFI values were highest in malaria endemic samples diluted at 1:100 for all antigens. Nine samples showed a small increase in MFI from a 1:100 to a 1:200 dilution for the MSP $-1_{42}$ alleles, suggesting a minor prozone effect, but the differences were smaller than the decreases seen with a decrease in dilution from 1:100 to 1:200 with all other 


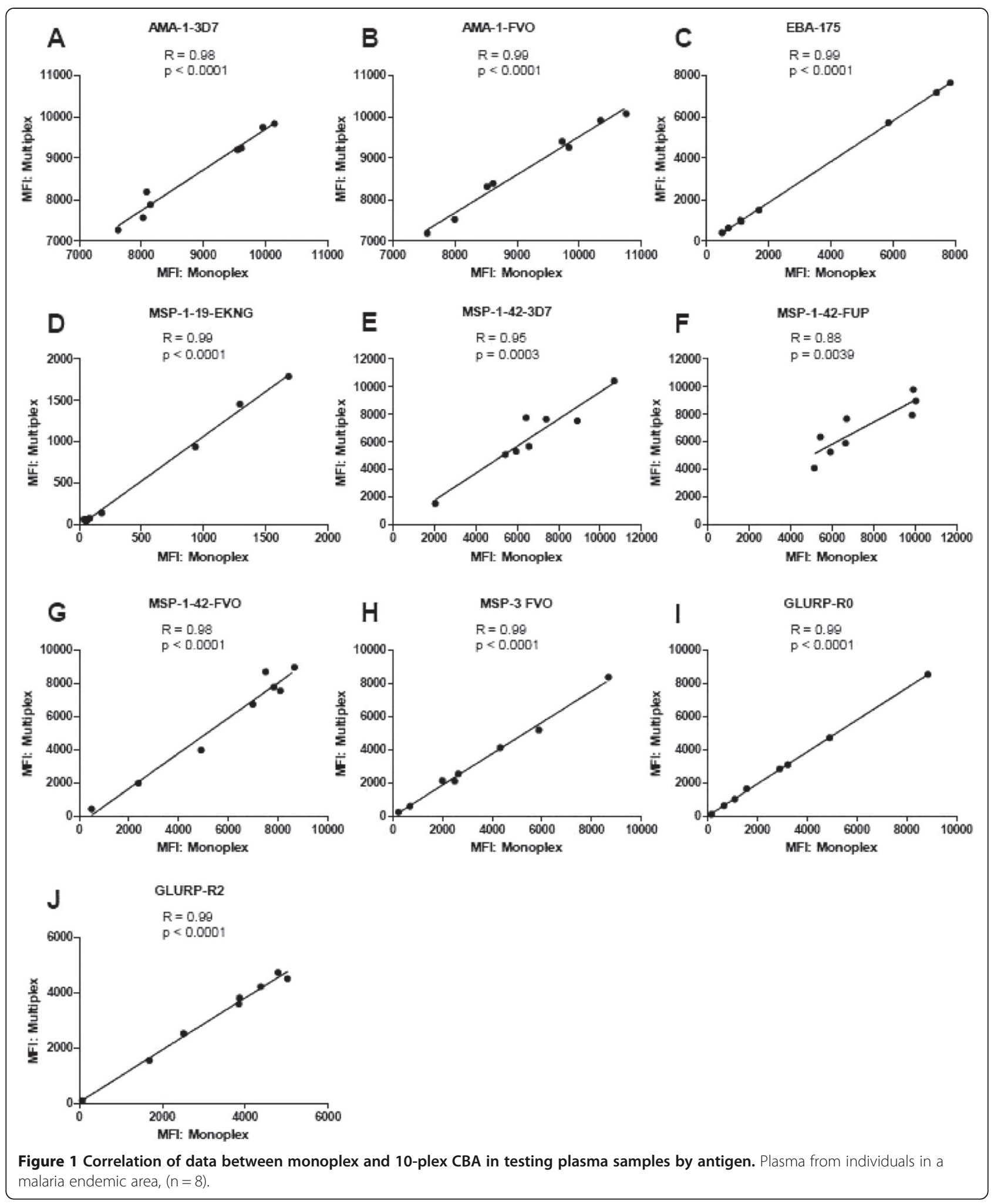


A

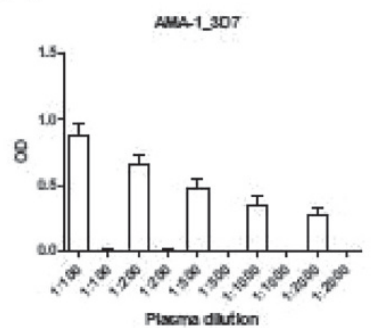

C

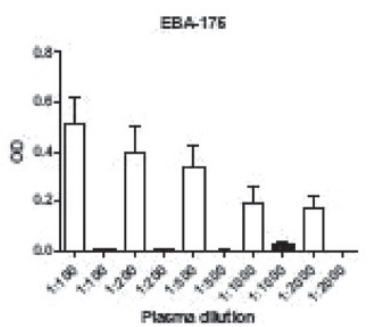

E

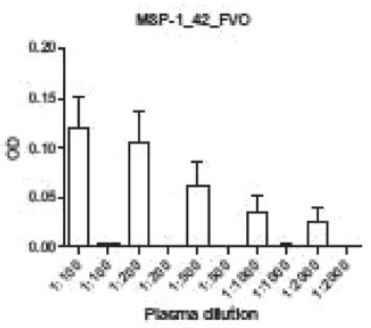

G

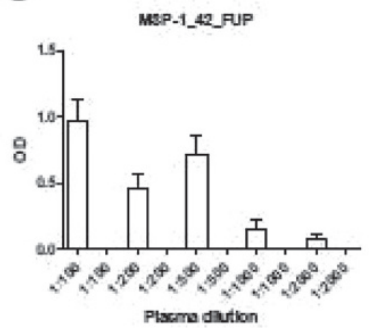

I

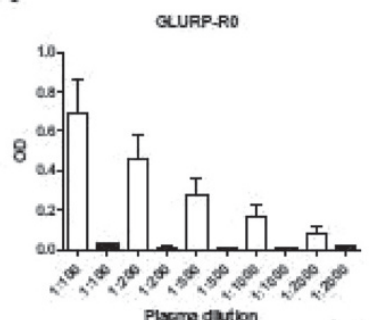

B

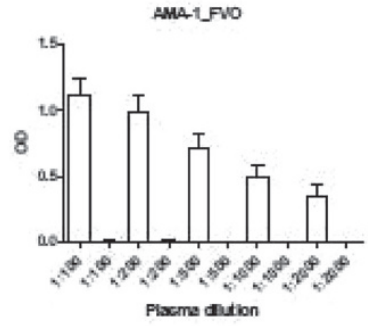

D

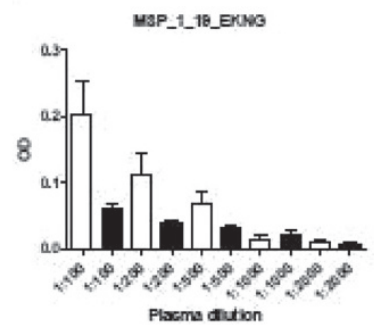

F

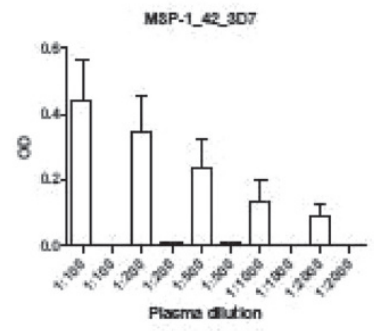

$\mathrm{H}$

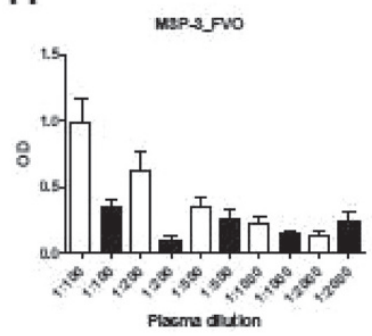

$J$

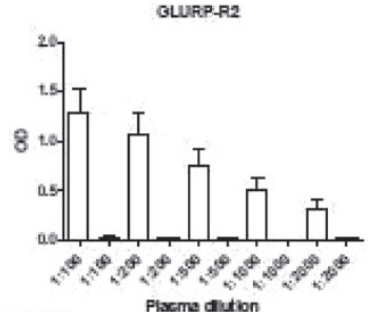

口 Pixma from PC

Figure 2 Effect of plasma dilution on IgG antibody ELISA OD values of plasma from persons in a malaria endemic area, $(n=30)$ and persons never exposed to malaria, $(\mathbf{n}=7) . \mathrm{OD}=$ optical density. $\mathrm{OD}$ values on $\mathrm{Y}$-axis differ according to antigen. 


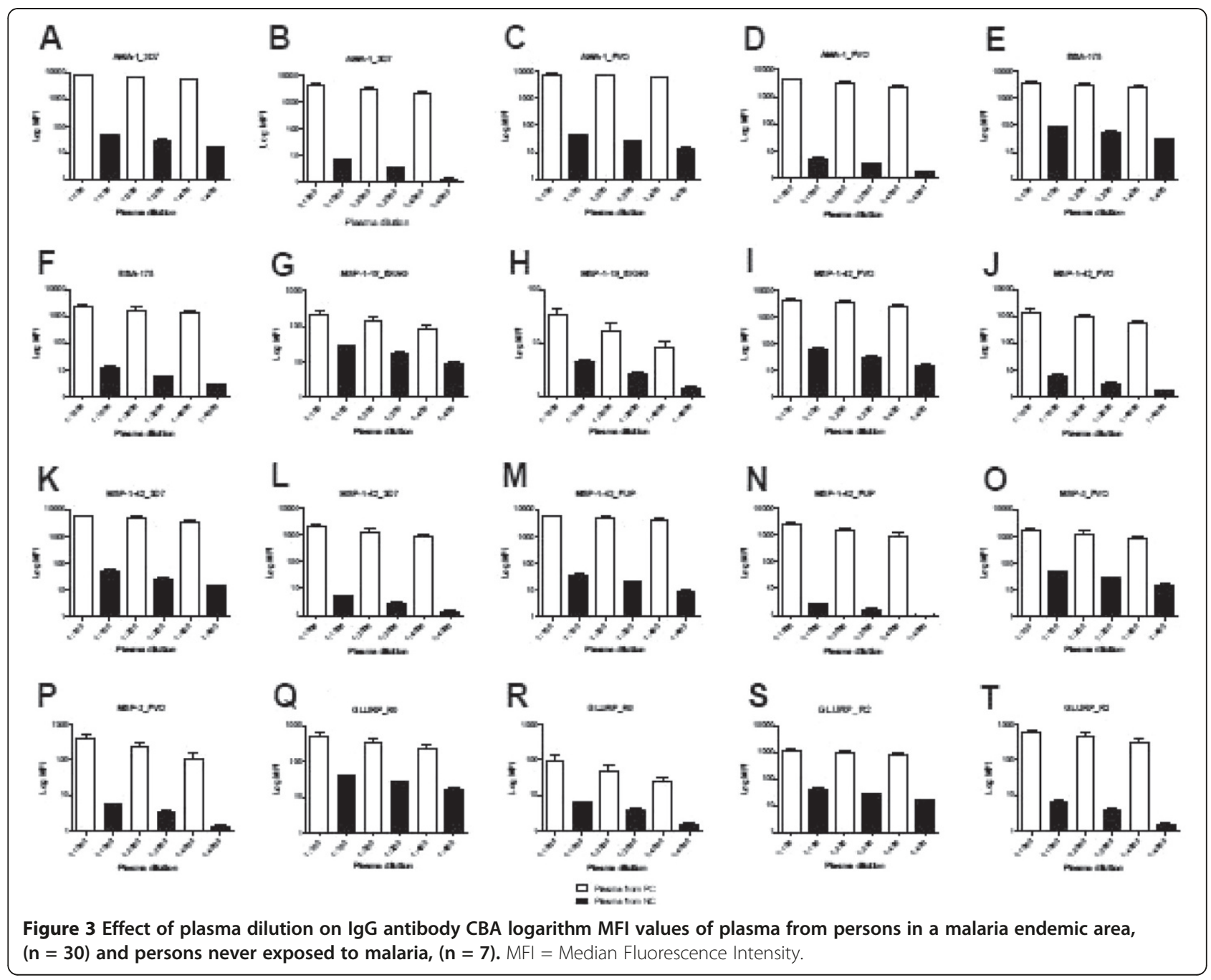

samples. An example was for MSP- $1_{42}$ FUP, for which antibody MFI values increased for five persons and decreased for 25 persons from a malaria endemic area (Figure 4).

Samples from North American individuals never exposed to malaria also showed an approximately normal distribution at all dilutions for 1:100, 1:200, 1:400 and 1:2000 dilutions for MSP-1 $1_{42}$ FUP (Figure 5). In contrast, ELISA values for North American control samples showed much greater variability, did not decrease with increasing plasma dilution (Figure 2), and were often not normally distributed for 1:100, 1:200, 1:500 and 1:2000 dilutions (e.g., for MSP- $1_{42}$ FUP, Figure 6). MFI values of blank wells (beads in diluent buffer only) in CBA testing were almost uniformly 0 or 1 , making background reactivity a non-issue with CBA testing (Figure 7), while blank wells in ELISA testing sometimes had low and sometimes high OD readings (Figure 8), creating more variability in assessment of the North American control

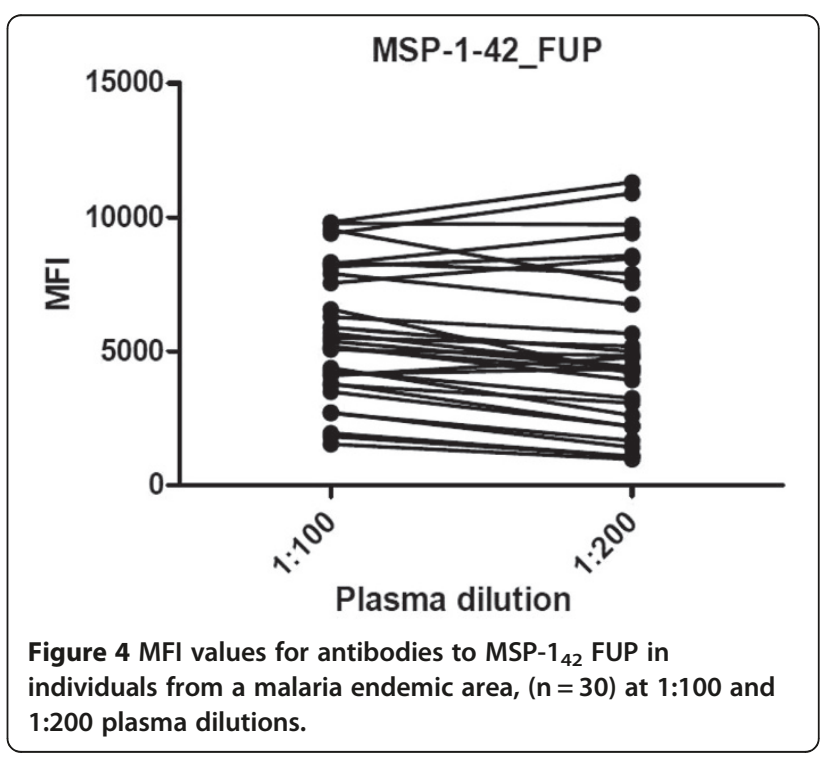




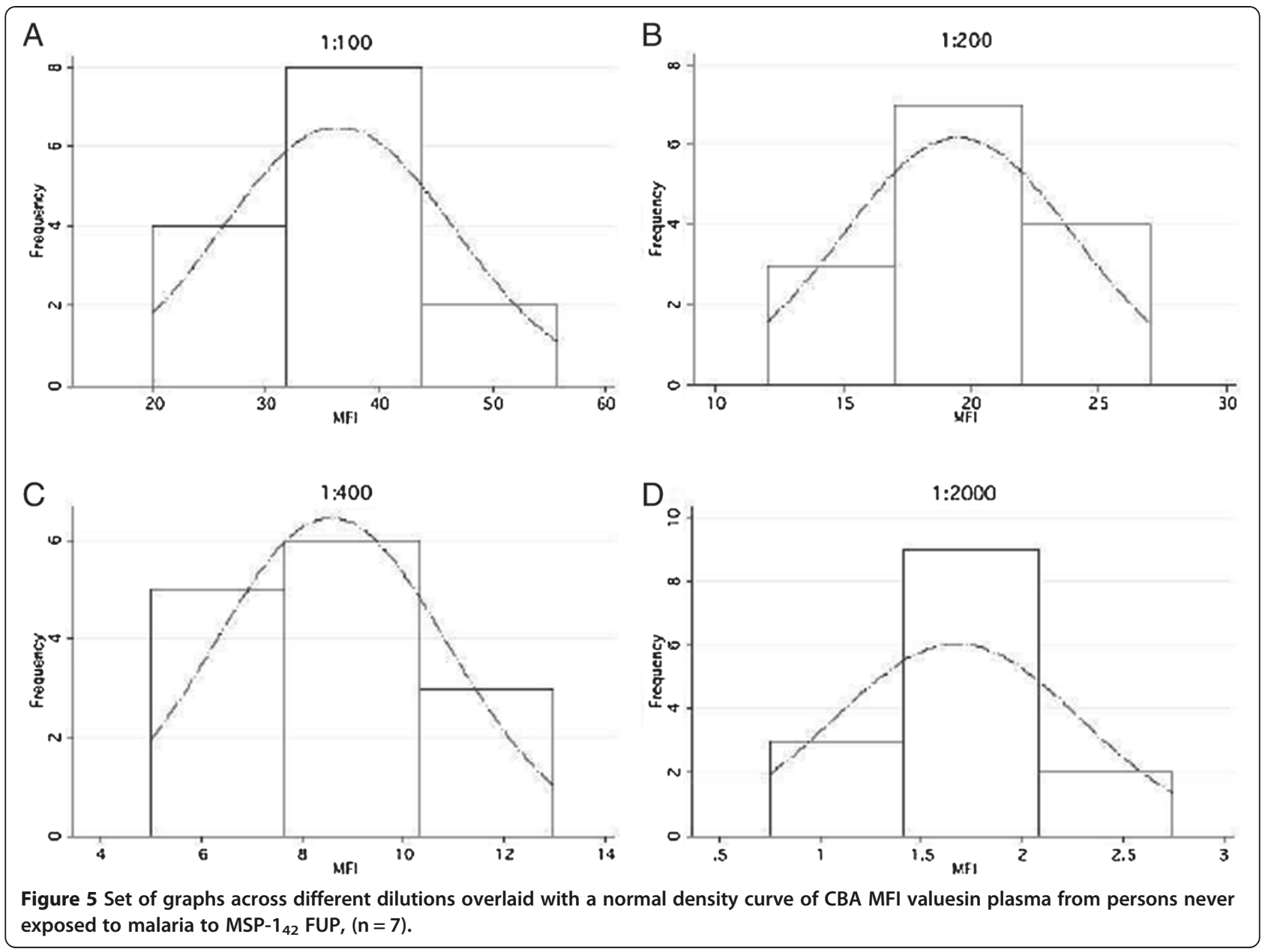

and malaria endemic sample OD values, if blank OD values are subtracted from the control and malaria endemic sample values.

For CBA or ELISA testing in which there is no reference standard for antibody concentration, arbitrary units (AU) are often used to define antibody levels. Arbitrary units are used to standardize antibody values across plates [22]. For antibodies to P. falciparum antigens, AU is calculated using plasma samples from individuals (in this study, North Americans) never exposed to malaria. The mean OD or MFI of the North American plasma samples plus three standard deviations of the OD or MFI values is the cutoff value for $1 \mathrm{AU}$. The same North American samples are tested on every plate. Every test sample is then divided by the cutoff OD or MFI value to come up with an AU value, and a sample is categorized as "positive" by either multiplex or ELISA if the AU value us greater than $\geq 1$. For this study, 30 North American control samples were tested, and seven samples chosen that are representative of the 30 samples, providing the same mean and standard deviation, for each plate, as testing all 30 samples on each plate would almost double the number of plates required. It is particularly important with this method, which has been used by others [22-26] that the samples provide a nonskewed range of MFI or OD values. The increased range, consistently normal distribution of North American control samples, and lower background values obtained with CBA as compared to ELISA, made calculation of arbitrary units more accurate and reliable with CBA than with ELISA.

For CBA, plasma dilutions of 1:100 or 1:200 generally provided the best combination of AU range and sufficient discrimination between North American control samples and blank (diluent alone) wells. At dilutions greater than 1:400, MFI values became so low (e.g., mean (SD) values for MSP-3 for 1:1000, 1:2000 and 1:5000 were 5.5 (1.4), 3.6 $(0.9)$ and $1.4(0.5)$, respectively) that although they were higher than the blank well values of 0 or 1 , they were considered too close to the blank well values to be useful in calculating arbitrary units. Together, the findings lead to a conclusion that a plasma dilution of 1:100 or 1:200 was optimal for most antigens in the CBA assay to allow determination of antibody level for the antigen in an individual. 


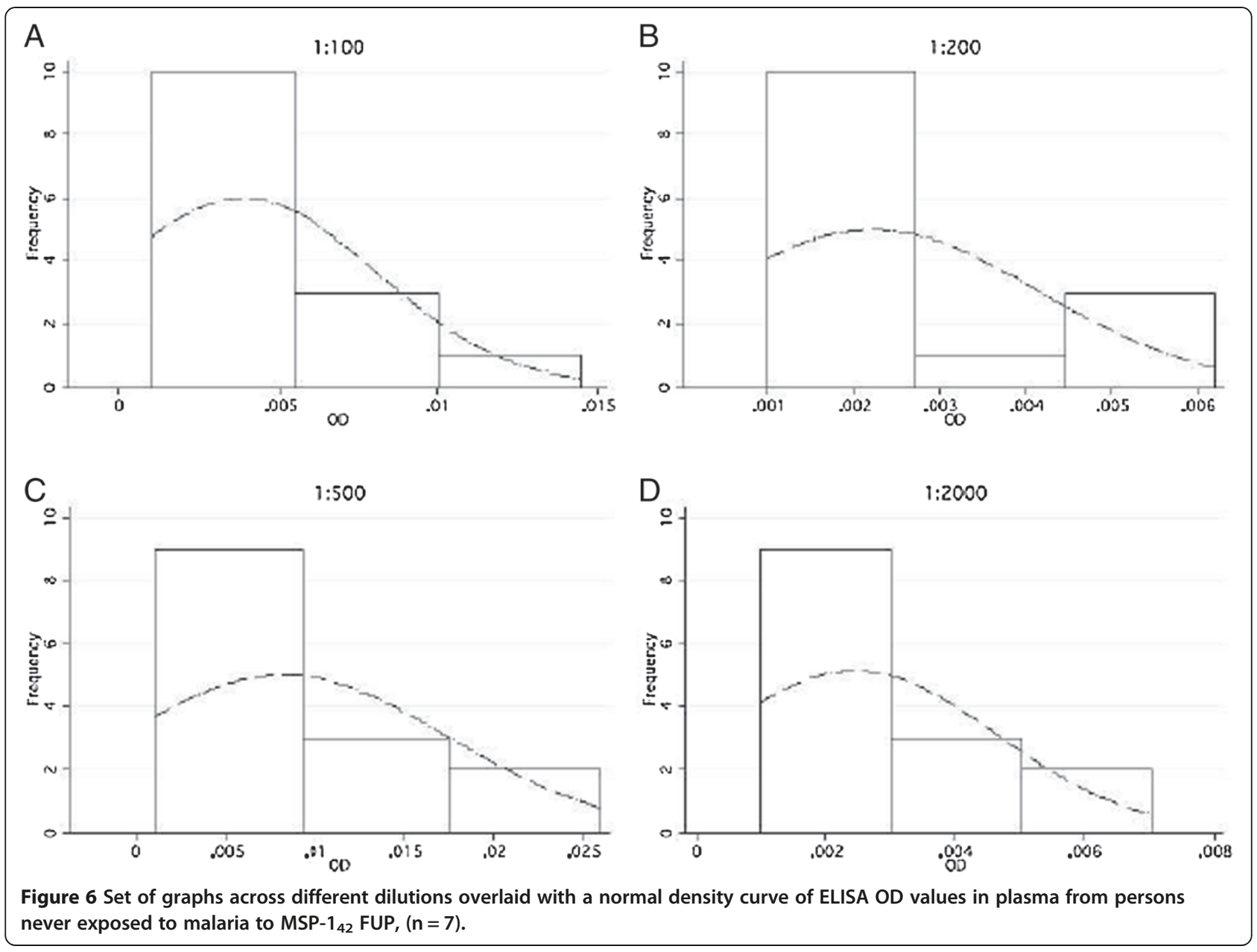

Because of the few samples with increase MFI at 1:200 for the MSP-1 $1_{42}$ antigens, a 1:200 dilution was chosen as the standard dilution for CBA.

AU values as calculated from ELISA testing had a much smaller range of minimum to maximum values than corresponding values calculated from CBA testing. For all antigens, a 1: 100 plasma dilution appeared to be the optimal dilution for ELISA testing.

\section{Reducing non specific background reactivity in CBA testing}

To investigate reduction of non-specific background reactivity, two buffers were compared with plasma pooled from North American individuals (a mixture of seven North American plasma samples) and positive pooled samples. Pooled samples of each type were tested in quadruplicate for each buffer at a dilution of 1:200. Buffer A (1xPBS, 0.1\% BSA, 0.05\% Tween 20, and $0.05 \%$ sodium azide, $\mathrm{pH} 7.4$ ) was compared to Buffer B (1xPBS, 1\% BSA, 0.05\% Tween 20, 0.05\% sodium azide, $0.5 \%$ polyvinylalcohol, $0.8 \%$ polyvinylpyrrolidone, $\mathrm{pH} 7.4$; see Methods section for rationale). The two buffers were compared using a six-plex CBA (AMA-1
3D7, AMA-1 FVO, EBA-175, MSP-1 42 3D7, MSP-1 42 FUP and MSP-1 42 FVO).

The two buffers yielded similar MFI values for the positive pool samples for all, (Figure 9A), with statistically significant differences only for EBA-175 (buffer B > buffer $\mathrm{A}$ ) and $\mathrm{MSP}-1_{42}$ FUP (buffer $\mathrm{A}>$ buffer $\mathrm{B}$ ). In contrast, MFI values for the non-malaria exposed North American plasma pool were significantly lower for buffer $\mathrm{B}$ for all six antigens (Figure 9B). The pooled positive plasma samples also had reduced bead aggregation when buffer B was used compared to buffer A. Buffer B thus provided greater differentiation in MFI values between plasma samples from malaria-exposed as compared to non-exposed individuals.

\section{Optimizing the number of beads per CBA analyte per well}

Standard testing protocols for CBA recommend 5,000 beads per analyte per well [3,11,12,27-29], but using large numbers of beads significantly increases expense. The number of beads per region per well used for each analyte throughout the optimization process was 5,000 as per microsphere manufacturer's recommendations. 


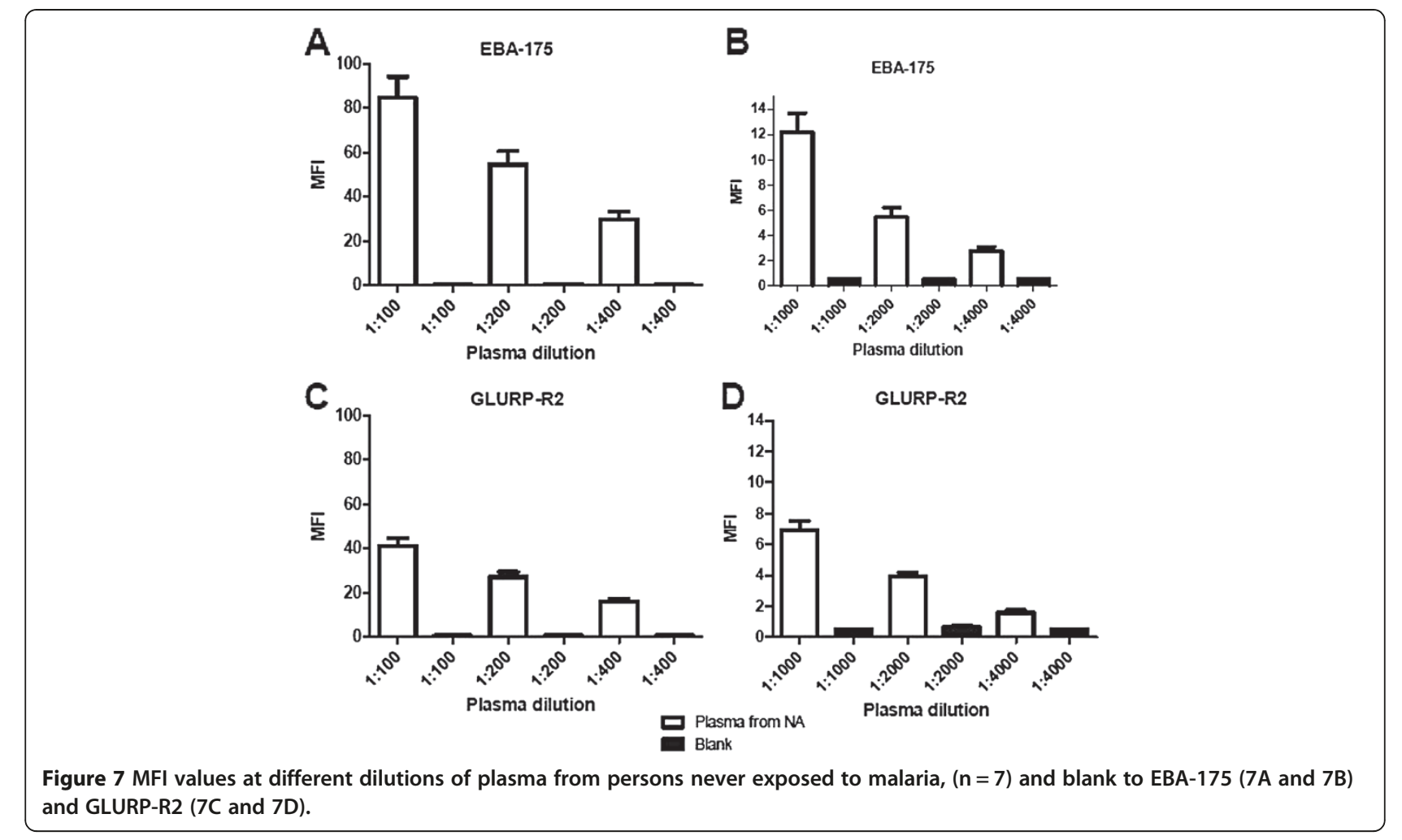

To determine if similar results could be obtained with a lower number of beads, a comparison of MFI values obtained with 5,000 beads/analyte/well and 1,000 beads/ analyte/well was performed. For this comparison purposes, sixteen plasma samples from individuals from a malaria endemic area of Kenya, three North American control samples, and one positive pool sample, all diluted to 1:200 were tested. MFI values were essentially identical for all antigens tested with the two different bead numbers (all $r \geq 0.99$, all $P<0.0001$ ), (Figure 10). A minimum of 100 beads/well was read by the bioplex machine for each analyte.

\section{Reproducibility of the CBA coupling process}

To evaluate the reproducibility of the coupling process, coupling reactions were performed on two different days (one week apart). Having established the optimal amounts of antigen suitable for coupling, 612,500 beads were coupled to respective optimal amounts to AMA- 1 3D7 and GLURP-R0 and 2-plex antibody detection was performed using a positive plasma pool sample, two North American control samples, and three samples from individuals from malaria endemic Kenya, all diluted 1:200 Absolute MFI values generated between the two coupling reactions were compared. The two coupling reactions produced almost identical results (both $r \geq 0.99$, $P<0.0001$ ) (Figure 11).

\section{Concordance between multiplex CBA and ELISA assay}

OD values by ELISA and MFI values by CBA were compared for samples from 20 individuals from malaria endemic Kenya and North Americans. Correlations between CBA and ELISA were strong $(r>0.7)$ and highly significant $(P<0.001)$ for all antigens except AMA-1, (Figure 12).

\section{Discussion}

A number of recent papers have used multiplex CBA testing to assess for the presence of antibodies to P. falciparum antigens $[8,10]$. In this study, a comprehensive assessment of experimental parameters to optimize multiplex cytometric bead assay (CBA) testing of antibodies to $P$. falciparum antigens is provided. A recent paper by Ambrosino et al. characterized optimization of plasma dilution and amount of antigen for CBA malaria antibody testing and focused on testing antibodies to peptides of various $P$. falciparum antigens. This paper adds to the findings of prior papers by assessing optimal plasma dilution and antigen amount for several recombinant antigens not previously tested, investigating antigenic variants in the same multiplex testing, establishing optimal diluent buffer for the lowest background reactivity, and demonstrating that the testing can be performed accurately with significantly less beads than have previously been used in malaria studies. This study also demonstrates the specific advantages CBA 

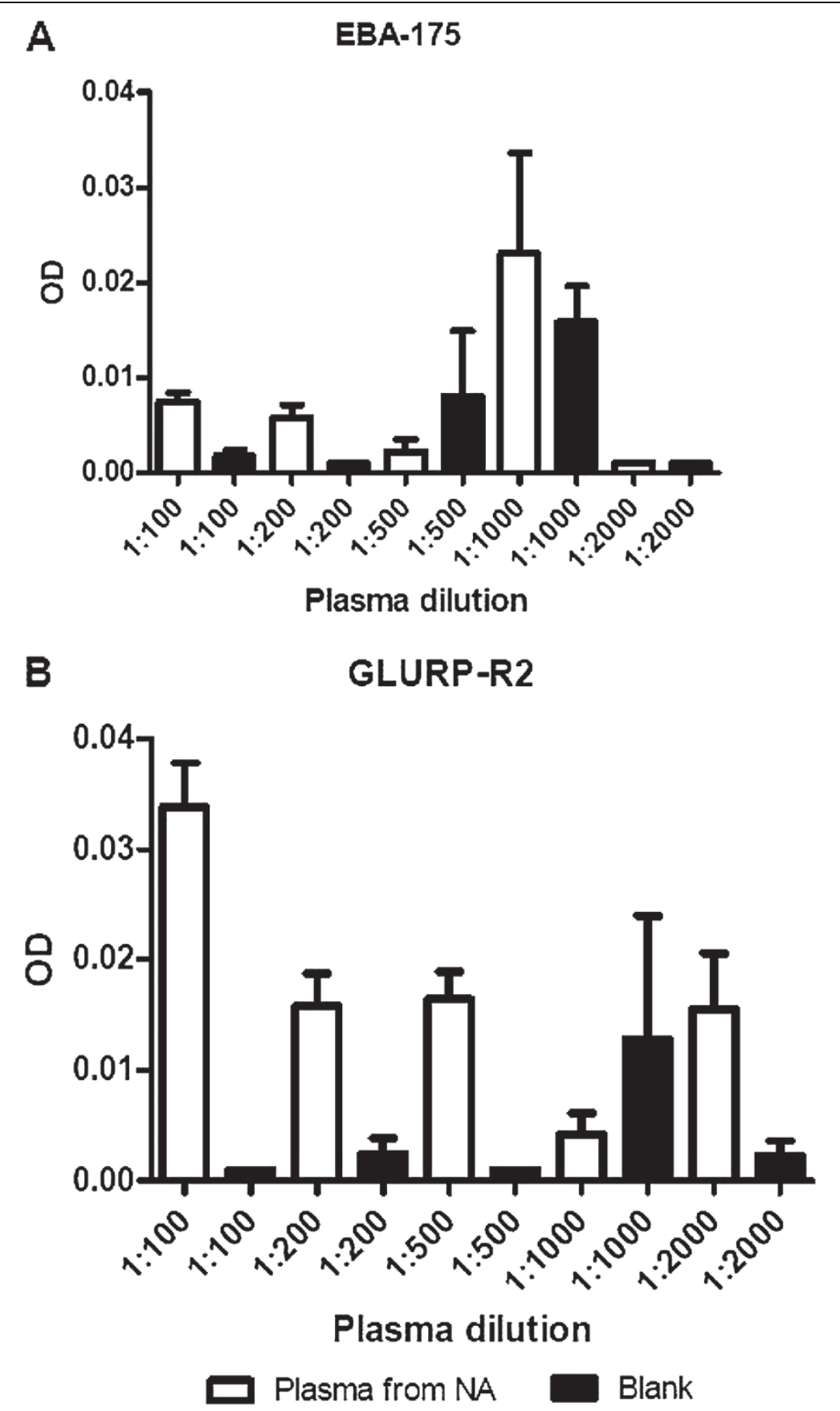

Figure 8 OD values at different dilutions of plasma from persons never exposed to malaria, $(n=7)$ and blank to EBA-175 $(8 A)$ and GLURP-R2 (8B).

may have over ELISA in antibody testing when there is no absolute reference standard, and relative units must be devised using samples from individuals without exposure to the pathogen to compare measurements of exposed populations.

Prior studies have documented similar results for CBA and ELISA for measurement of antibodies to P. falciparum or Plasmodium vivax antigens in malaria endemic populations $[11,12]$. Studies of antibodies to other infectious organisms have similarly shown that CBA compares well to established reference assays for these organisms [30-33]. Advantages noted over ELISA include specimen conservation, the ability to measure multiple analytes simultaneously, reduction in sample processing time due to kinetics 


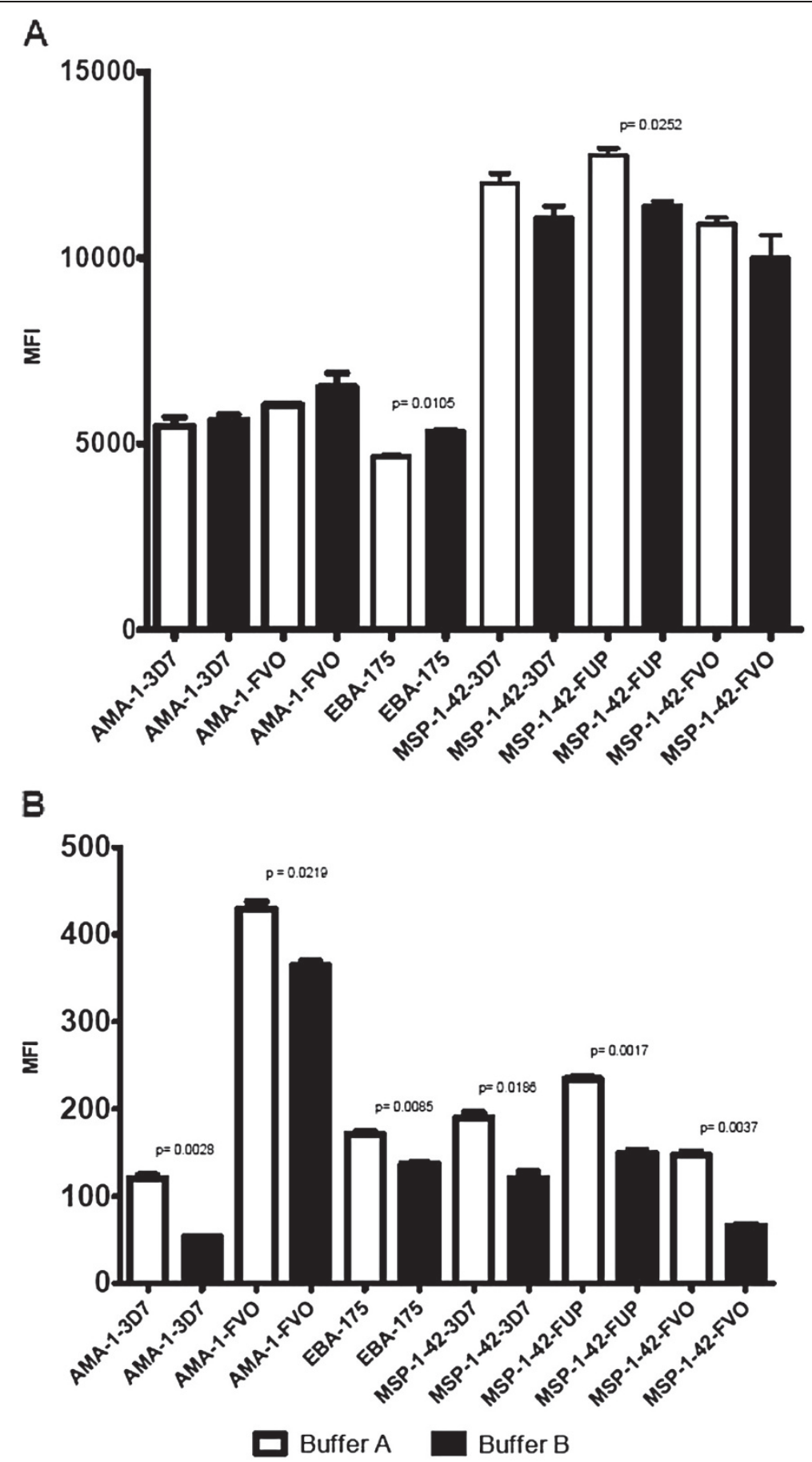

Figure 9 Comparison of CBA MFI values to P. falciparum antigens using Buffer A vs. Buffer B. plasma pool from persons in a malaria endemic area (Figure 9A) and plasma pool from persons never exposed to malaria (Figure 9B).

of the assay, and cost minimization. The present study adds to this literature by demonstrating optimization of antigen concentration, plasma dilution, buffer solution, and number of beads. The study demonstrates that antibodies to antigenic variants can be tested in the same well (multiplex) and results are virtually identical to results of testing any variant alone by CBA (monoplex). It also provides evidence for the superiority of this testing as compared to ELISA testing in terms of providing less background, better differentiation of "positive" responses, 


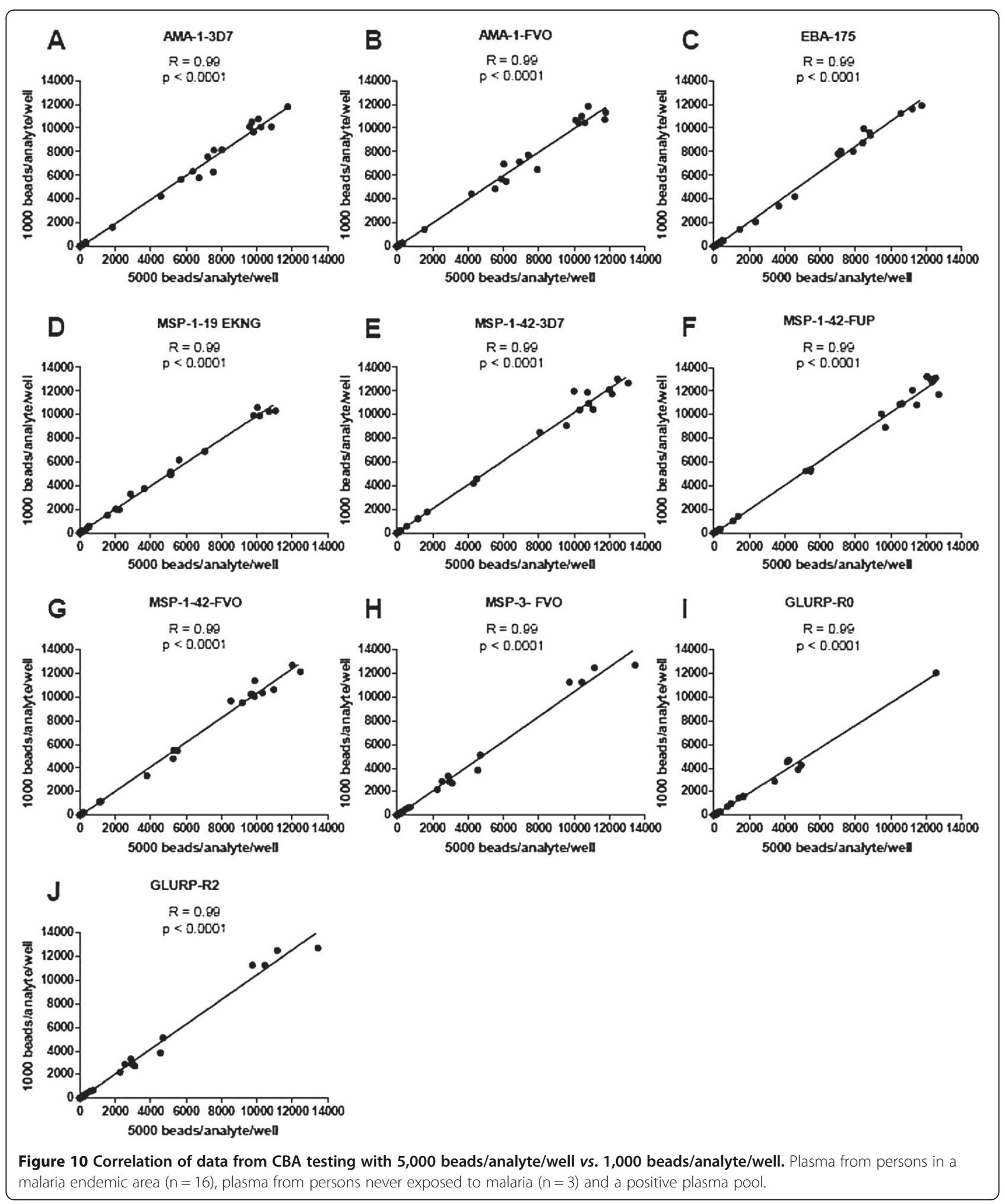




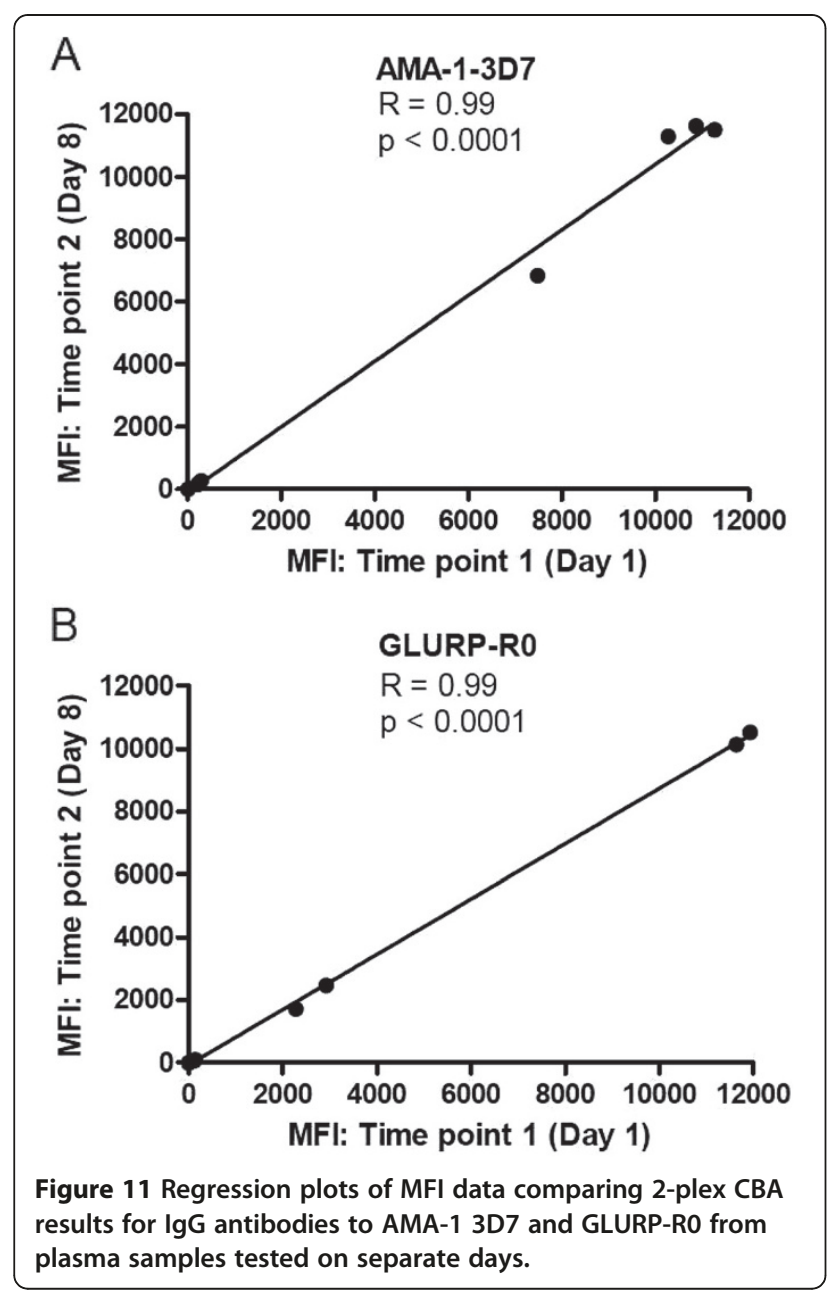

and a broader dynamic range of antibody level values. Together, these findings support CBA as a precise, accurate and efficient alternative to ELISA for testing antibodies to multiple $P$. falciparum antigens, including multiple variants of the same antigen.

Determining appropriate working amounts of antigens is important in controlling surface density of the malaria antigens on the bead surface. Coupling small amounts may result in sub-optimal coating and low activity (less antibody binding), while too much antigen could result in precipitation and aggregation of the beads on the bottom of the microtiter well surface and this may impair the surface suspension antibody binding. Additionally, one would like to use the lowest amount of antigen that will provide the desired binding of antigens [34]. Reduction of background activity will enable malaria immunologists to accurately measure low-level antibodies, particularly in travellers $[7,35,36]$ and in individuals under medication or individuals who are in recovery phase since antibodies have been shown to decline after malaria episodes $[37,38]$.

Comparison between the 10-plex CBA and individual ELISA assays showed strong and highly significant correlations for all antigens except AMA-1 (Figure 12). The reasons for this discrepancy with AMA-1 are not clear. AMA-1 is among the most immunogenic $P$. falciparum antigens, and average MFI values for both AMA-1 variants were much higher than for other antigens, while OD values showed a similar distribution to that seen for other antigens. Low values were seen for both assays with North American controls, so it is not clear which assay more accurately reflected the range of AMA-1 antibody values in this population. This study documented an increase in MFI going from a plasma dilution of 1:100 to 1:200 for a few individuals for the antigen MSP $-1_{42}$ only. This suggested evidence of a modest prozone phenomenon in these individuals. These findings demonstrate that some degree of compromise is required in decisions on a final dilution, as one dilution may not be the ideal for all antigens.

In the present study, long-term storage of multiplex beads, to see how long they could be used was not tested. Other studies have found that they provide slightly reduced MFI values after 7 and 12 months after initial bead coupling, if stored at $4^{\circ} \mathrm{C}[39,40]$. Future studies will be required to confirm the study findings and assess longer storage periods of the coupled beads. Lyophilization of coupled bead sets, as used in a recent study [9], may provide an attractive alternative for long-term use of the same bead sets on different samples over time.

\section{Conclusion}

The findings from the present study provide a basis for improved multiplex CBA testing, as the study testing provides information that will allow those testing by CBA to reduce background reactivity, optimize antigen concentration and plasma dilution, and use a five-fold lower number of beads for testing. Protocols will need to be individually tailored for specific antigens, but the results here provide a clear template for testing protocols that will allow for rapid customization and comparison testing. The present study also provides evidence of the increased dynamic range of CBA testing as compared to ELISA for this testing. The methods described in this study should assist in standardizing multiplex CBA antibody testing for multiple $P$. falciparum antigens, and allow it to become an important tool in seroepidemiology studies assessing population-based immunity in the face of changing transmission. 


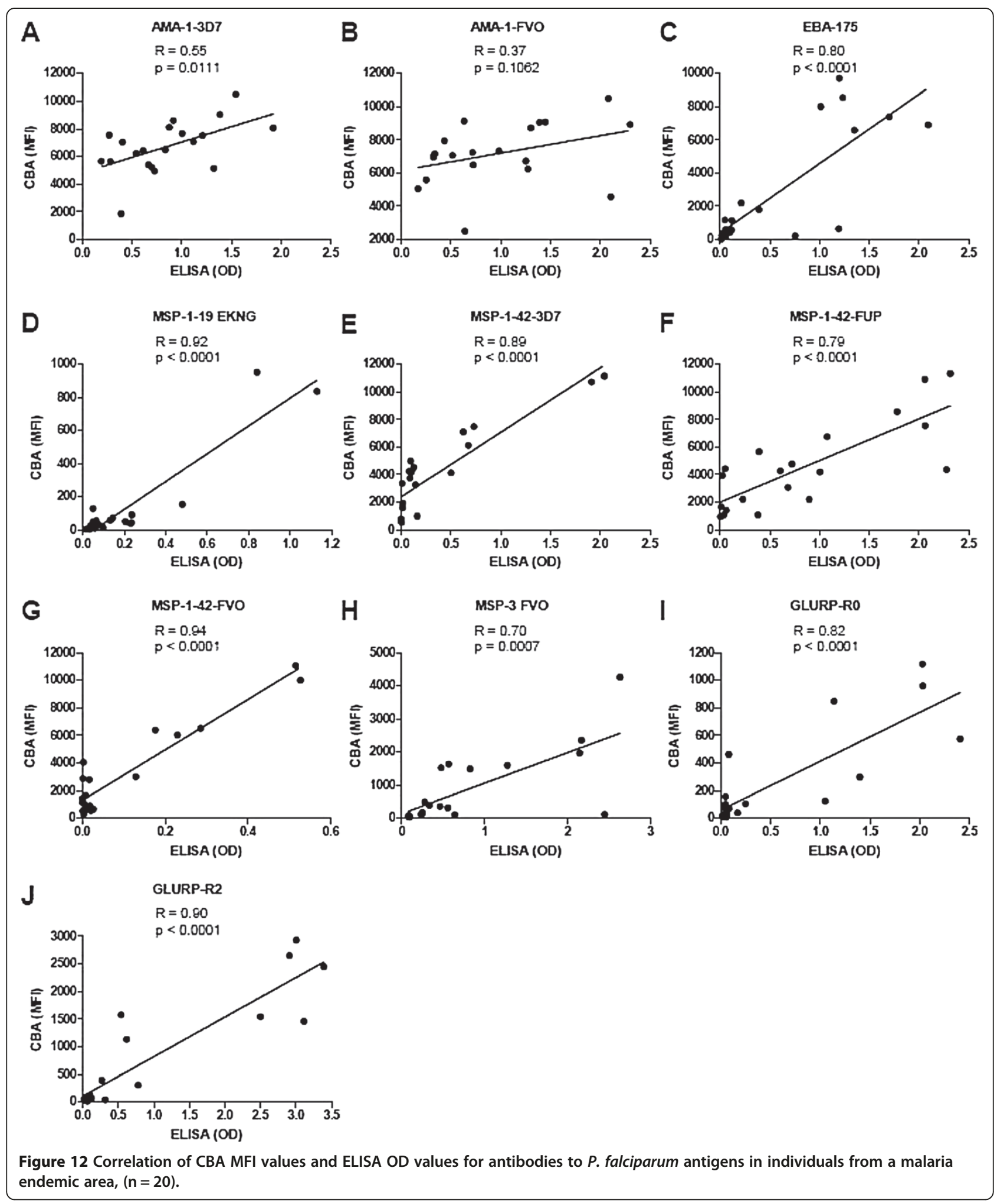




\section{Competing interest}

The authors declare that no competing interests exist. The director of Kenya Medical Research Institute approved this article for publication.

\section{Authors' contributions}

BNO helped in the design aspects of the study, validated and performed assays, literature search, data analysis, drafting of the manuscript and transferring technology to field laboratory. SOG and BMH validated and performed assays and data acquisition. GSP assisted in data acquisition, helped in the design aspects of the study and intellectual content of the manuscript. GAA, LAO and AVO provided intellectual input and revision of the manuscript. CCJ conceived the idea and led the study design, implementation of the program and drafting of the manuscript and editing and review of the manuscript. All authors read and approved the final manuscript.

\section{Source of support}

CCJ is supported by National Institutes of Health (U01 Al056270), and BNO is supported by Fogarty International center (D43 TW0080085) and Government of Kenya Ministry of Higher Education Science and Technology, National Council of Science and Technology PhD competitive funds.

\section{Acknowledgements}

The authors thank Grace Meyer for assistance in performing ELISA and David Narum, David Lanar, Michael Theissen and Malaria Research and Reference Reagent Resource Center (MR-4) for provision of recombinant antigens used in the testing. The authors are also grateful to the study participants and the director KEMRI.

\section{Author details}

${ }^{1}$ Department of Biomedical Science and Technology, Maseno University, Maseno, Kenya. ${ }^{2}$ Department of Pediatrics, University of Minnesota, Minneapolis, MN, USA. ${ }^{3}$ Center for Global Health Research, Kenya Medical Research Institute, Kisumu, Kenya.

Received: 5 July 2012 Accepted: 20 December 2012

Published: 21 December 2012

\section{References}

1. Noland GS, Hendel-Paterson B, Min XM, Moomann AM, Vulule JM, Narum DL, Lanar DE, Kazura JW, John CC: Low prevalence of antibodies to preerythrocytic but not blood-stage Plasmodium falciparum antigens in an area of unstable malaria transmission compared to prevalence in an area of stable malaria transmission. Infect Immun 2008, 76:5721-5728.

2. Olutu A, Lusingu J, Leach A, Lievens M, Vekemans J, Msham S, Lang T, Gould J, Dubois MC, Jongert E, Vansadia P, Carter T, Njuguna P, Awuondo KO, Malabeja A, Abdul O, Gesase S, Mturi N, Drakeley CJ, Savarese B, Villafana T, Lapierre D, Ballou WR, Cohen J, Lemnge MM, Peshu N, Marsh K, Riley EM, von Seidlein L, Bejon P: Efficacy of RTS, S/AS01E malaria vaccine and exploratory analysis on anti-circumsporozoite antibody titres and protection in children aged 5-17 months in Kenya and Tanzania: a randomised controlled trial. Lancet Infect Dis 2011, 11:102-109.

3. Lal G, Balmer P, Stanford E, Martin S, Warrington R, Borrow R: Development and validation of a nonaplex assay for the simultaneous quantitation of antibodies to nine Streptococcus pneumoniae serotypes. J Immunol Methods 2005, 296:135-147.

4. Cham GK, Kurtis J, Lusingu J, Theander TG, Jensen AT, Turner L: A semiautomated multiplex high-throughput assay for measuring lgG antibodies against Plasmodium falciparum erythrocyte membrane protein 1 (PfEMP1) domains in small volumes of plasma. Malar J 2008, 12:108.

5. Vignali DA: Multiplexed particle-based flow cytometric assays. J Immunol Methods 2000, 243:243-255.

6. Giavedoni LD: Simultaneous detection of multiple cytokines and chemokines from nonhuman primates using luminex technology. J Immunol Methods 2005, 301:89-101.

7. Ambrosino E, Dumoulin C, Orlandi-Pradines E, Remoue F, Toure-Balde A, Tall A, Sarr JB, Poinsignon A, Sokhna C, Puget K, Trape JF, Pascual A, Druilhe P, Fusai T, Rogier C: A multiplex assay for the simultaneous detection of antibodies against 15 Plasmodium falciparum and Anopheles gambiae saliva antigens. Malar J 2010, 9:317.
8. Cham GK, Turner L, Kurtis JD, Mutabingwa T, Fried M, Jensen AT, Lavstsen T, Hviid L, Duffy PE, Theander TG: Hierarchial, domain type-specific acquisition of antibodies to Plasmodium falciparum erythrocyte membrane protein 1 in Tanzania children. Infect Immun 2010, 78:4653-4659.

9. Cham GK, Turner L, Lusingu J, Vestergaard L, Mmbando BP, Kurtis JD, Jensen AT, Salanti A, Lavstsen T, Theander TG: Sequential, ordered acquisition of antibodies to Plasmodium falciparum erythrocyte membrane 1 domains. J Immunol 2009, 183:3356-3363.

10. Chang SP, Kayatani AK, Terrientes ZI, Herrera S, Leke RG, Taylor DW: Shift in epitope dominance of IgM and IgG responses to Plasmodium falciparum MSP1 block 4. Malar J 2010, 9:14.

11. Fouda GG, Leke RF, Long C, Druilhe P, Zhou A, Taylor DW, Johnson AH: Multiplex assay for simultaneous measurement of antibodies to multiple Plasmodium falciparum antigens. Clin Vaccine Immunol 2006, 13:1307-1313.

12. Fernandez-Becerra C, Sanz S, Brucet M, Stanisic DI, Alves FP, Camargo EP Alonso PL, Mueller I, de Portillo HA: Naturally- acquired humoral immune responses against the $\mathrm{N}$ - and $\mathrm{C}$ - termini of the Plasmodium vivax MSP1 protein in endemic regions of Brazil and Papua New Guinea using a multiplex assay. Malar J 2010, 9:29.

13. Idro R, Bitarakwate E, Tumwesigire S, John CC: Clinical manifestations of severe malaria in the highlands of southwestern Uganda. Am J Trop Med Hyg 2005, 72:561-567.

14. John CC, Moormann AM, Pregibon DC, Sumba PO, McHugh MM, Narum DL, Lanar DE, Schluchter MD, Kazura JW: Correlation of high levels of antibodies to multiple pre-erythrocytic Plasmodium falciparum antigens and protection from infection. Am J Trop Med Hyg 2005, 73:222-228.

15. Waterboer T, Sehr P, Pawlita M: Suppression of non-specific binding in serological Luminex assays. J Immunol Methods 2006, 309:200-204.

16. Dodoo D, Theisen M, Kurtzhals JA, Akanmori BD, Koram KA, Jepsen S, Nkrumah FK, Theander TG, Hviid L: Naturally acquired antibodies to the glutamate-rich protein are associated with protection against Plasmodium falciparum malaria. J Infect Dis 2000, 181:1202-1205.

17. Lusingu J, Vestergaard LS, Alifrangis M, Mmbando BP, Theisen M, Kitua AY, Lemnge MM, Theander TG: Cytophilic antibodies to Plasmodium falciparum glutamate rich protein are associated with malaria protection in an area of holoendemic transmission. Malar J 2005, 4:48.

18. Nébié I, Cuzin-Ouattara N, Diallo DA, Cousens SN, Theisen M, Corradin G, Traoré AS, Esposito F: Humoral responses to defined malaria antigens in children living since birth under insecticide treated curtains in Burkina Faso. Acta Trop 2003, 88:17-25.

19. Theisen M, Dodoo D, Toure-Balde A, Soe S, Corradin G, Koram KK, Kurtzhals JA, Hviid L, Theander TG, Akanmori B, Ndiaye M, Druilhe P: Selection of glutamate-rich protein long synthetic peptides for vaccine development: antigenicity and relationship with clinical protection and immunogenicity. Infect Immun 2001, 69:5223-5229.

20. Diallo TO, Remoue F, Gaayeb L, Schacht AM, Charrier N, De Clerck D, Dompnier JP, Pillet S, Garraud O, N'Diaye AA, Riveau G: Schistosomiasias coinfection in children influences acquired immune response against Plasmodium falciparum malaria antigens. PLoS One 2010, 5:e12764.

21. Segeja MD, Mmbando BP, Seth MD, Lusingu JP, Lemnge MM: Acquisition of antibodies to merozoite surface protein 3 among residents of Korogwe, north eastern Tanzania. BMC Infect Dis 2010, 10:55.

22. Fidock DA, Gras-Masse H, Lepers JP, Brahimi K, Benmohamed L, Mellouk S, Guerin-Marchand C, Londono A, Raharimalala L, Meis JF: Plasmodium falciparum liver stage antigen- 1 is well conserved and contains potent $B$ and T cell determinants. J Immunol 1994, 153:190-204.

23. Ceravolo IP, Sanchez BA, Sousa TN, Guerra BM, Soares IS, Braga EM, McHenry AM, Adams JH, Brito CF, Carvalho LH: Naturally acquired inhibitory antibodies to Plasmodium vivax Duffy binding protein are short-lived and allele-specific following a single malaria infection. Clin Exp Immunol 2009, 156:502-510.

24. Dent AE, Chelimo K, Sumba PO, Spring MD, Crabb BS, Moomann AM, Tisch DJ, Kazura JW: Temporal stability of naturally acquired immunity to Merozoite Surface Protein- 1 in Kenyan adults. Malar J 2009, 8:162.

25. Richards JS, Stanisic DI, Fowkes FJ, Tavul L, Dabod E, Thompson JK, Kumar S, Chitnis CE, Narum DL, Michon P, Siba PM, Cowan AF, Mueller I, Beeson JG: Association between naturally antibodies to erythrocyte-binding antigens of Plasmodium falciparum and protection from malaria and high-density parasitemia. Clin Infect Dis 2010, 51:e50-e60.

26. Storti-Melo LM, Souza-Neiras WC, Cassiano GC, Taveira LC, Cordeiro AJ, Couto VS, Póvoa MM, Cunha MG, Echeverry DM, Rossit AR, Arévalo-Herrera 
M, Herrera S, Machado RL: Evaluation of the naturally acquired antibody immune response to the Pv200L N-terminal fragment of Plasmodium vivax merozoite surface protein-1 in four areas of the Amazon Region of Brazil. Am J Trop Med Hyg 2011, 84:58-63.

27. Bay JT, Garred P: Rapid bead-based immunoassay for measurement of mannose-binding lectin. Scand J Immunol 2009, 69:570-575.

28. de Vore NC, Huynh S, Dobrovolskaia EN, Slater JE: Multiplex microbead measurements for the characterization of cat and ragweed allergen extracts. Ann Allergy Asthma Immunol 2010, 105:351-358.

29. Sun M, Manolopoulou J, Spyroglou A, Beuschlein F, Hantel C, Wu Z, Bielohuby M, Hoeflich A, Liu C, Bidlingmaier M: A microsphere-based duplex competitive immunoassay for the simultaneous measurements of aldosterone and testosterone in small sample volumes: validation in human and mouse plasma. Steroids 2010, 75:1089-1096.

30. Reder S, Riffelmann M, Becker C, Wirsing von Konig CH: Measuring immunoglobulin $\mathrm{G}$ antibodies to tetanus toxin, diphtheria toxin, and pertusis toxin with single- antigen enzyme- linked immunosorbent assays and a bead-based multiplex assay. Clin Vaccine Immunol 2008, 15:744-749.

31. Shoma S, Verkaik NJ, de Vogel CP, Hermans PW, van Selm S, Mitchell TJ, van Roosmalen M, Hossain S, Rahman M, Endtz HP, van Wamel WJ, van Belkum A: Development of a multiplexed bead-based immunoassay for the simultaneous detection of antibodies to 17 pneumococcal proteins. Eur $J$ Clin Microbiol Infect Dis 2011, 30:521-526.

32. van der Heyde HC, Burns JM, Weidanz WP, Horn J, Gramaglia I, Nolan JP: Analysis of antigen-specific antibodies and their isotypes in experimental malaria. Cytometry A 2007, 71:242-250.

33. Wagner B, Freer H, Rollins A, Erb HN: A fluorescent bead-based multiplex assay for the simulaneous detection of antibodies to $B$. burgdorferi outer surface proteins in canine serum. Vet Immunol Immunopathol 2011, 140:190-198.

34. TechNote 204: Adsorption to microspheres. Bang Laboratories, Inc; 2008.

35. Jelinek T, Blüml A, Löscher T, Nothdurft HD: Assessing the incidence of infection with Plasmodium falciparum among international travelers. Am J Trop Med Hyg 1998, 59:35-37.

36. Zamarrón Fuertes P, Pérez-Ayala A, Pérez Molina JA, Norman FF, MongeMaíllo B, Navarro M, López-Vélez R: Clinical and epidemiological characteristics of imported infectious diseases in Spanish travelers. $J$ Travel Med 2010, 17:303-309.

37. Achtman AH, Bull PC, Stephens R, Langhorne J: Longevity of the immune response and memory to blood- stage malaria infection. Curr Top Microbiol Immunol 2005, 297:71-102.

38. Kinyanjui SM, Conway DJ, Lanar DE, Marsh K: IgG antibody responses to Plasmodium falciparum merozoite antigens in Kenyan children have a short half-life. Malar J 2007, 6:82.

39. Crompton PD, Kayala MA, Traore B, Kayentao K, Ongoiba A, Weiss GE, Molina DM, Burk CR, Waisberg M, Jasinkas A, Tan X, Doumbo S, Doumtabe D, Kone Y, Narum DL, Liang X, Doumbo OK, Miller LH, Doolan DL, Baldi P, Felgner PL, Pierce SK: A prospective analysis of the Ab response to Plasmodium falciparum before and after a malaria season by protein microarray. Proc Natl Acad Sci U S A 2010, 107:6958-6963.

40. Cham GK, Kurtis J, Lusingu J, Theander TG, Jensen AT, Turner L: A semiautomated multiplex high-throughput assay for measuring $\lg G$ antibodies against Plasmodium falciparum erythrocyte membrane protein 1 (PfEMP1) domains in small volumes of plasma. Malar J 2008, 7:108.

doi:10.1186/1475-2875-11-427

Cite this article as: Ondigo et al: Standardization and validation of a cytometric bead assay to assess antibodies to multiple Plasmodium falciparum recombinant antigens. Malaria Journal 2012 11:427.

\section{Submit your next manuscript to BioMed Central and take full advantage of:}

- Convenient online submission

- Thorough peer review

- No space constraints or color figure charges

- Immediate publication on acceptance

- Inclusion in PubMed, CAS, Scopus and Google Scholar

- Research which is freely available for redistribution

Submit your manuscript at www.biomedcentral.com/submit 